Original Research Paper

\title{
Investigation of Factors Influencing the Reproduction of Non-Gregarious Locust Pests in Northern Kazakhstan to Substantiate the Forecast of their Number and Planning of Protective Measures
}

\author{
${ }^{1}$ Kurmet Baibussenov, ${ }^{1}$ Aigul Bekbaeva, ${ }^{1}$ Valery Azhbenov, ${ }^{2}$ Amageldy Sarbaev and ${ }^{1}$ Svetlana Yatsyuk \\ ${ }^{1}$ S. Seifullin Kazakh Agro Technical University, Nur-Sultan, Republic of Kazakhstan \\ ${ }^{2}$ Kazah National Agrarian Research University, Almaty, Republic of Kazakhstan
}

Article history

Received: 25-12-2020

Revised: 12-03-2021

Accepted: 17-03-2021

Corresponding Author:

Kurmet Baibussenov

S. Seifullin Kazakh Agro

Technical University, Nur-

Sultan, Republic of Kazakhstan

Email: kurmet-baibussenov@mail.ru

\begin{abstract}
The article presents the results of many years of research on the phytosanitary state of agricultural land for non-gregarious locust pests. As polyphagous pests, non-gregarious locusts are one of the key destabilizing factors in the production of economically important agricultural plants in the agricultural regions of Northern Kazakhstan. Research on the long-term population dynamics of non-gregarious locust pests to determine bioecological regularities and factors influencing them for early forecasting an increase in the number and rational planning of plant protection products is very relevant. The studies were carried out in 1999-2019 based on the use of data on the distribution of non-gregarious locusts in Akmola, Pavlodar, Kostanay and North Kazakhstan regions. Numerical indicators of pest colonization and abundance indices were used as diagnostic predictors characterizing the phase state of species in a given year, which made it possible to establish patterns of population dynamics of locusts. Based on the research results, the authors concluded that the expected onset of certain phases of the dynamics of the phytophagous population was not always preserved and was subject to change under the influence of environmental factors. The trend in the dynamics of the number of studied phytophages depends to a large extent on the weather conditions of the previous and current year, as well as on the full amount of volumes and compliance with the necessary procedures. The data obtained can be proposed as criteria for predicting the phase state of populations of non-gregarious locusts in Northern Kazakhstan to justify and plan protective measures, as well as to improve phytosanitary control over non-gregarious locusts.
\end{abstract}

Keywords: Phytosanitary Monitoring and Prognosis, Population Dynamics, Non-Gregarious Locust Pests, Protective Measures, Northern Kazakhstan

\section{Introduction}

Sustainable development of the agro-industrial complex is one of the priority areas in many countries of the world, including Kazakhstan (Tokbergenova et al., 2018). The development of this area is associated with the currently relevant green technologies in agriculture and the basic principles of sustainable development, rational use of resources, conservation of biodiversity and reduction of the negative impact of pesticides on the environment (Zhang et al., 2019; Abdalla, 2014; SICAICMARK, 2020).
One of the factors contradicting the conservation of biodiversity and ensuring phytosanitary safety is massive pesticide treatments used against locust pests as the only method of crop protection in cases of exacerbation of the phytosanitary situation (Baibussenov et al., 2014). Despite the annually carried out massive treatments against locusts, nowhere is the phytosanitary situation as critical as in arid and subarid zones, which occupy most of the territory of Kazakhstan (Kurishbaev and Azhbenov, 2013; Baybussenov et al., 2015; Azhbenov et al., 2015). 
Locusts are the most dangerous pests of economically important agricultural plants in dry and arid climates in Africa, Australia, the Middle East, East and Southeast Asia (Malakhov and Zlatanov, 2020). Insects can periodically massively reproduce under the influence of anthropogenic influences, global climate warming and other factors (Latchininsky and Sivanpillai, 2010; Cressman, 2016). According to the UN Food and Agricultural Organization (FAO), in the countries of Central Asia, including Kazakhstan, outbreaks of mass reproduction of certain dangerous species of locust pests occur almost every year (FAOUN, 2020).

The most effective of the locust control methods is the use of pesticides, based on the high biological effect of chemicals on the insect and ground and ultra-lowvolume spraying are key protective measures against these pests (FAOUN, 2014). However, the technology based on the massive use of pesticides during the period of outbreaks and infestations of locusts requires huge expenses, destabilizes the ecological situation and increases the pesticide load on ecosystems.

The locust control strategy should change depending on scientific and technological progress, agricultural technologies and attitude to environmental protection. As an alternative, a transition from massive pesticide treatments to the preventive management of the populations of cannabis was proposed (Kurishbaev and Azhbenov, 2013). This approach takes into account all aspects of phytosanitary safety, including preparedness and contingency plans.

The issue of non-gregarious locust pest management in the agricultural regions of Northern Kazakhstan, which cause no less harm than common locusts, remains relevant (Axelsen et al., 2009; Sergeev, 2010). In these regions, cereals are grown in large areas, primarily spring wheat with high-quality gluten indicators and many other economically important crops.

The prevailing non-gregarious locust pests in the agricultural areas of Northern Kazakhstan are Dociostaurus brevicollis (Ev.), Dociostaurus kraussi kraussi kraussi (Ingen.), Stauroderus scalaris (F.-W.), Aeropus sibiricus sibiricus (L.), Pararcyptera microptera (F.-W.), Chorthippus albomarginatus albomarginatus (Deg.), Euchorthippus pulvinatus (F-W.) (Childebaev and Kazenas, 2013; Akmollaeva, 2004).

In the northern states of the USA and Canada, countries with similar climatic conditions to the northern part of Kazakhstan, information is provided on the harmfulness of such non-gregarious locusts as Melanoplus differenttialis, Schistocerc anitens, Schistocercaa mericana and other species, where annual damage to agricultural lands from these pests amounts to 20-30\% (Lockwood and Sergeev, 2000). According to the estimates of American specialists, non-gregarious locust pests in the north of the USA annually cause damage to crops that equals 400 million USD (Hassanali et al., 2005). If we talk about the cost of protective measures, then in Wyoming alone, 7.4 million USD was spent on pest management during the years of the increase in the pest population (McNary et al., 2011).

In Kazakhstan, due to the polyphagous nature of these phytophages and the direct proximity of crops to pasture lands, there is a high risk in the event of their mass colonization. According to the results of previous research results (Baibusenov et al., 2014), nongregarious locust pests can cause damage to agricultural land yield up to $41.1 \%$. It has been established that with a population of fewer than 8 individuals $/ \mathrm{m}^{2}$, the yield loss is $14.3-16.1 \%$ and with a population of more than 10 individuals $/ \mathrm{m}^{2}$, it can reach $38.6-41.1 \%$.

Until now, much attention has been paid to protective measures against non-resident locusts based on the Economic Threshold of Harmfulness (ETH) of their number. After the population reaches a certain ETH, it is necessary to carry out protective measures. Besides, studies of the dynamics of the number of phytophages were carried out, which made it possible to establish the features of the development and reproduction of nongregarious locusts (Baibussenov et al., 2014).

To effectively manage populations of non-gregarious locusts, it is necessary to improve the phytosanitary forecast methods for the rational planning of protective measures (Lomer et al., 2001). Today, there are many questions regarding the interaction of the abundance of locust pests with the environment and what unique features these insects have in comparison with other living organisms (Ariel and Ayali, 2015).

The purpose of this study is to analyze the population dynamics of non-gregarious locust pests in their entirety and to identify the regular trends of their reproduction, population structure, phase variability and dynamics of the number of phytophages in the agricultural regions of Northern Kazakhstan. Locusts, in contrast to many other insect pests, are distinguished by an extremely dynamic population and phase variability of the population. Therefore, the establishment of patterns of changes in the dynamics of the number of phytophages and diagnostic predictors of forecasting populations is a priority task in improving the phytosanitary control of locusts.

The use of the results obtained makes it possible to improve phytosanitary monitoring and the progression of non-gregarious locusts, as well as to substantiate effective protective measures during the transition from massive pesticide treatments to the preventive management of locust populations. 


\section{Materials and Methods}

The objects of the study were the most common nongregarious locust species, such as Pararcyptera microptera microptera (F.-W.), Dociostaurus brevicollis (Ev.) and Podisma pedestris (L.).

The study used methods for analyzing the dynamics of the number and population structure of pest species (Sagitov et al., 2016). To study the dynamics of the number and establish the phase of population variability of insects, we used data on the distribution of nongregarious locusts in Akmola, Pavlodar, Kostanay and North Kazakhstan regions for the period from 1999 to 2019 (MARK, 1999-2019).

The phases of population variability of locusts (depression-population increase-mass reproductionpopulation peak-population decline) have been established using statistical and mathematical methods based on an analysis of the dynamics of population numbers over many years (Azhbenov, 2013). In locusts, five phases of population variability are distinguished: Depression is the phase when the population is very small and remains only in areas of normal abundance; population increase occurs when the living conditions for the species improve and biotopic populations capable of intensive reproduction are formed; mass reproduction is the phase where pests are characterized by high vitality and increased resistance to mortality factors, their number is growing rapidly; population peak is the phase when reproduction weakens, the resistance of populations to mortality factors decreases, natural enemies become more active and resistance to pesticides decreases; population decline is the phase where the populations do not reproduce and remain only in areas of normal abundance (Dubrovin et al., 2011).

The establishment of the phase of population variability of non-gregarious locusts was carried out according to the indicators of the pest colonization and the abundance level and abundance indices (Azhbenov, 2013). The main indicators of locust colonization and values of the locust abundance level are the relative $\left(\mathrm{Col}_{\text {rel }}\right)$, basic $\left(\mathrm{Col}_{\text {bas }}\right)$ and absolute $\left(\mathrm{Col}_{a b s}\right)$ colonization calculated using formulas 1-3:

$$
\begin{aligned}
& \operatorname{Col}_{r e l}=A_{c o l} * 100 / A_{\text {sur }} \\
& \operatorname{Col}_{\text {bas }}=\left[A_{c o l}(O-5) D_{a v}(0-5)\right]+\ldots+ \\
& {\left[A_{c o l}(>30) D_{a v}(>30)\right] / A c o l} \\
& C l_{a b s}=C_{\text {Col }} * \operatorname{Col}_{\text {bas }} / 100
\end{aligned}
$$

where, $\mathrm{Col}_{\text {rel }}$ is the relative colonization in $\%, A_{\text {col }}$ is the colonized area in thousand hectares, $A_{c o l}(0-5), . .(>30)$ is the colonized area with the colonization density in individuals per $1 \mathrm{~m}^{2}$ in thousand hectares, Asur is the surveyed area in thousand hectares, Col bas is the basic colonization in individuals per $1 \mathrm{~m}^{2}$, Dav (0-5) ... 030; is the average density of the population in individuals per $1 \mathrm{~m}^{2}$, Col $_{a b s}$ is the absolute colonization in individuals per $1 \mathrm{~m}^{2}$.

The abundance indices describing the intensity and phase of the breeding status of the population include the coefficient of dispersity $\left(C_{d i s}\right)$, the coefficient of colonization $\left(C_{c o l}\right)$, the reproduction coefficient $\left(C_{r e p}\right)$, the energy of dispersal $\left(E_{d i s}\right)$, the energy of reproduction $\left(E_{r e p}\right)$ and the coefficient of progradation $\left(C_{p r}\right)$, calculated using formulas 4-9:

$$
\begin{aligned}
& C_{d i s}=\operatorname{Col}_{r e l(i)} / \operatorname{Col}_{\text {rel }(i-1)} \\
& C_{c o l}=\operatorname{Col}_{\text {bas }(i)} / \operatorname{Col}_{\text {bas }(i)} / \operatorname{Col}_{\text {bas }(i-1)} \\
& C_{r e a}=C_{d i s} * C_{c o l} \\
& E_{d i s}=C_{d i s(i)} * C_{d i s(i-1)} \\
& E_{r e a}=C_{r e a(i)} * C_{r e a(i-1)} \\
& C_{a r}=E_{d i s} * E_{r e a}
\end{aligned}
$$

Where, $C_{d i s}, C_{c o l}, C_{r e p}$ and $C_{p r}$ are the coefficients of dispersal, colonization, reproduction and progradation, $E_{d i s}$ and $E_{r e p}$ are the energy of dispersal and reproduction, Col $_{\text {rel }}, \mathrm{Col}_{\text {bas }}$ and $\mathrm{Col}_{a b s}$ are the relative, basic and absolute colonization, $\mathrm{j}$ is the indicator in the $j$ th year, $(\mathrm{j}-$ $1)$ is the indicator in the $(j-1)$ th year.

Selyaninov Hydrothermal Coefficient (HTC) was calculated using formula 10 :

$C=R * 10 / \Sigma t$

where, $R$ is the sum of precipitation in millimeters for the period with temperatures above $+10^{\circ} \mathrm{C}, \Sigma t$ is the sum of temperatures in $\left({ }^{\circ} \mathrm{C}\right)$ for the same time.

\section{Results and Discussion}

\section{The Main Patterns of Population Dynamics of Non- Gregarious Locust Pests in Northern Kazakhstan}

As a result of the analysis of data on the distribution of locusts in Akmola, Pavlodar, Kostanay and North Kazakhstan regions for the period from 1999 to 2019, we established the dynamics of the colonization indicators and values of the abundance level by years, as well as the abundance indices of non-gregarious locusts.

Table 1 shows the dynamics of the colonization indices and the abundance level of non-gregarious locusts, such as relative $\left(\mathrm{Col}_{\text {rel }}\right)$, basic $\left(\mathrm{Co}_{\mathrm{lbas}}\right)$ and absolute ( Col $\left._{a b s}\right)$ colonization for 1999-2019. 
Quantitative changes in population processes over time can be displayed using abundance indices. These indicators characterizing the change in the number of non-gregarious locusts, the intensity of reproduction and the dynamics of populations include the coefficients of dispersal $\left(C_{d i s}\right)$, colonization $\left(C_{c o l}\right)$, reproduction $\left(C_{r e p}\right)$, progradation $\left(C_{p r}\right)$ and the energy of dispersal $\left(E_{d i s}\right)$ and reproduction $\left(E_{r e p}\right)$.

Table 2 presents the dynamics of indicators of the index of the number of non-gregarious locusts, including the coefficient of dispersal $\left(C_{d i s}\right)$, the coefficient of colonization $\left(C_{c o l}\right)$, the coefficient of reproduction $\left(C_{\text {rep }}\right)$, the energy of dispersal $\left(E_{d i s}\right)$, the energy of reproduction $\left(E_{\text {rep }}\right)$ and the coefficient of progradation $\left(C_{p r}\right)$ for 1999-2019.

Figure 1 shows the dynamics of the indices of the number of non-gregarious locusts, such as the coefficients of reproduction $\left(C_{r e p}\right)$ and progradation $\left(C_{p r}\right)$ and the energy of dispersal $\left(E_{\text {dis }}\right)$ and reproduction $\left(E_{\text {rep }}\right)$ by year for 1999-2019 in the agricultural regions of Northern Kazakhstan.

From the data in Table 2 and Fig. 1, it can be seen that the greatest prognostic value is represented by yearto-year variations in the relative and absolute colonization $\left(\mathrm{Col}_{\mathrm{rel}}, \mathrm{Col}_{a b s}\right)$, the energy of dispersal and reproduction $\left(E_{d i s}, E_{r e p}\right)$ and the coefficients of reproduction and progradation $\left(C_{r e p}, C_{p r}\right)$.

Table 3 shows the established diagnostic predictors of the state of the phases of the population dynamics of nongregarious locusts (depression-population increase-mass reproduction-population peak-population decline) and Table 4, based on these diagnostic predictors, identifies the analyzed years, which are characterized by one or another phase of the dynamics of phytophage populations.

From the data in Tables 3 and 4, we can see that, according to the diagnostic indicators of the onset of the population dynamics phase of non-gregarious locusts, depression took place in 2002 and 2003, population increase in 2001, 2004, 2007, 2008, 2015 and 2019, mass reproduction in 1999, 2005, 2009, 2012 and 2016, population peak in 2010, 2013 and 2017 and population decline in 2000, 2006, 2011, 2014 and 2018. However, the sequence of the onset of the phases of the dynamics of the locust population according to the "depressionpopulation increase-mass reproduction-population peakpopulation decline" scheme is not always observed. Thus, after the population decline in 2000, in 2001, there was a population increase, skipping the depression phase and in 2002, there was depression instead of an increase.

Factors of Population Dynamics of NonGregarious Locust Pests on Agricultural Land in Northern Kazakhstan

According to researchers (Yu et al., 2009), long-term fluctuations in the number of locust pests largely depend on weather and climatic conditions and various anthropogenic factors (pesticide treatments, agricultural technologies, etc.). Large-scale changes in agrocenoses have a noticeable effect on locust population dynamics. Under these conditions, the population increase and mass reproduction of phytophages lasted 4-5 years and the migration of insects from uncultivated lands to crops became regular (Toleubayev et al., 2007).

Meanwhile, fluctuations in the population dynamics of non-gregarious locusts depended to a greater extent on abiotic and, to a lesser extent, on biotic factors (Baibussenov et al., 2014). It turned out to be more convenient to characterize and express the peculiarities of weather and climatic conditions using indicators of the HTC since the HTC reflects both thermal conditions and moisture conditions of the year.

Various studies (Yao and Zhang, 2007; Stolyarov, 2000; Kurishbaev and Azhbenov, 2013) provide data on the relationship between solar activity cycles and the dynamics of the number of gregarious locust pests (the desert locust, the Italian locust, the Moroccan locust, the Asian locust). In our observations for 1999-2019, we found no correlation between non-gregarious locust pests and solar activity.

Of the anthropogenic and technogenic factors, the largest impact on the dynamics of the number of phytophages studied was exerted by large-scale land development, as well as violations of the regulations for carrying out protective measures or the complete absence of protective measures (Azhbenov et al., 2015).

Arid and hot growing seasons are favorable for the development and reproduction of locusts. Wet and cool weather, on the contrary, negatively affects their development and reproduction, leading to a decline in their numbers (Sergeev, 2010). To identify the relationship between the population dynamics of nongregarious locusts and weather and climatic conditions, an analysis was made between the following variables: HTC as an indicator of the hydrothermal coefficient of the analyzed year and $C_{p r}$ as the coefficient of pest population progradation for the analyzed year.

Figures 2 and 3 show the curves for the dynamics of the above indicators for the period from 1999 to 2019, which makes it possible to see the relationship between them.

From the data in Figs. 2 and 3, it can be seen that there is a relationship between the population dynamics of non-gregarious locusts and the HTC indicators in certain years. In general, the population increase coincides with dry and hot or warm years (HTC> $0.20-0.55)$ and the population decline is observed mainly in cool and rainy years with HTC values $\leq 0.75$ 0.90 . However, sometimes there are exceptions to the rules. Thus, in 2003, despite the dry and hot weather with the HTC $=0.3$, the depression phase continued, having begun in 2002 with the $\mathrm{HTC}=0.8$. The progradation coefficient $\left(C_{p r}\right)$, indicating the change in the dynamics of the number by years, was subject to 
sharp increases and drops in the period 1999-2006 and from 2006 to 2018, it was in a state of fluctuations.

Pesticide treatments have a great influence on the dynamics of the locust population, especially in cases of violation of regulations or when the areas to be treated with a population above the ETH remain untreated and migratory locusts populate new territories (Azhbenov et al., 2017).

Figure 4 shows the population dynamics by years in the area infested by non-gregarious locust pests above the ETH and the volume of chemical treatments with pesticides in Northern Kazakhstan in 1999-2019.

Table 1: Colonization of agricultural land by non-gregarious locusts in Northern Kazakhstan (Akmola, Kostanay, Pavlodar and North Kazakhstan regions), 1999-2019

\begin{tabular}{|c|c|c|c|c|c|}
\hline \multirow[b]{2}{*}{ Years } & \multirow[b]{2}{*}{$\begin{array}{l}\text { Surveyed area, } \\
\text { thousand ha Asur }\end{array}$} & \multirow[b]{2}{*}{$\begin{array}{l}\text { Colonized, } \\
\text { thousand ha Acol }\end{array}$} & \multicolumn{2}{|r|}{ Colonization } & \multirow[b]{2}{*}{ Absolute, individuals $/ \mathrm{m}^{2}$ Colabs } \\
\hline & & & Relative, \% Colrel & Basic, individuals $/ \mathrm{m}^{2}$ Colbas & \\
\hline 1999 & $7,650.5$ & $6,789.1$ & 88.7 & 6.30 & 5.50 \\
\hline 2001 & $8,312.2$ & $3,456.5$ & 41.5 & 8.10 & 3.30 \\
\hline 2002 & $1,455.5$ & 453.3 & 31.1 & 7.30 & 2.20 \\
\hline 2003 & $2,312.3$ & 789.9 & 34.1 & 5.60 & 1.90 \\
\hline 2004 & $1,154.7$ & 464.1 & 40.2 & 6.00 & 2.40 \\
\hline 2005 & 822.03 & 636.1 & 77.4 & 4.90 & 3.70 \\
\hline 2006 & $1,596.3$ & $1,027.8$ & 64.4 & 4.80 & 3.00 \\
\hline 2007 & $1,437.05$ & $1,045.9$ & 72.8 & 5.40 & 3.90 \\
\hline 2008 & $1,256.7$ & 917.4 & 73.0 & 6.00 & 4.30 \\
\hline 2009 & $1,467.9$ & $1,157.4$ & 78.8 & 6.70 & 5.20 \\
\hline 2010 & 832.9 & 701.6 & 84.2 & 5.70 & 4.70 \\
\hline 2011 & $1,185.5$ & 925.2 & 78.0 & 5.60 & 4.30 \\
\hline 2012 & $2,480.7$ & $2,001.2$ & 80.6 & 6.70 & 5.40 \\
\hline 2014 & $1,520.5$ & 957.9 & 76.1 & 3.50 & 2.90 \\
\hline 2015 & 452.1 & 368.2 & 81.4 & 6.30 & 5.10 \\
\hline 2016 & 450.0 & 389.9 & 86.6 & 6.70 & 5.80 \\
\hline 2017 & 373.7 & 295.8 & 79.1 & 7.30 & 5.70 \\
\hline 2018 & 345.3 & 213.8 & 61.9 & 2.30 & 1.40 \\
\hline 2019 & 337.0 & 276.7 & 82.1 & 3.30 & 2.70 \\
\hline$\overline{\mathrm{S}} \mathrm{x}$ & 761.52 & 388.97 & 3.58 & 0.42 & 0.28 \\
\hline$\Delta \mathrm{x}$ & $1,588.5$ & 811.4 & 7.50 & 0.88 & 0.58 \\
\hline
\end{tabular}

Table 2: The abundance indices of non-gregarious locusts in Northern Kazakhstan (Akmola, Kostanay, Pavlodar and North Kazakhstan regions), $1999-2019$

\begin{tabular}{|c|c|c|c|c|c|c|}
\hline Years & $\begin{array}{l}\text { Coefficient of } \\
\text { dispersal, } C_{d i s}\end{array}$ & $\begin{array}{l}\text { Coefficient of } \\
\text { colonization, } C_{c o l}\end{array}$ & $\begin{array}{l}\text { Coefficient of } \\
\text { reproduction, } C_{r e p}\end{array}$ & $\begin{array}{l}\text { Energy of } \\
\text { dispersal, } E_{d i s}\end{array}$ & $\begin{array}{l}\text { Energy of } \\
\text { reproduction, } E_{\text {rep }}\end{array}$ & $\begin{array}{l}\text { Coefficient of } \\
\text { progradation, } C_{p r}\end{array}$ \\
\hline 1999 & 2.1 & 0.8 & 1.60 & - & - & - \\
\hline 2000 & 0.3 & 0.1 & 0.03 & 0.6 & 0.04 & 0.02 \\
\hline 2001 & 1.4 & 8.1 & 11.20 & 0.4 & 0.80 & 0.30 \\
\hline 2002 & 0.7 & 0.9 & 0.60 & 0.9 & 7.10 & 6.30 \\
\hline 2003 & 1.0 & 0.7 & 0.70 & 0.7 & 0.40 & 0.20 \\
\hline 2004 & 1.1 & 1.0 & 1.10 & 1.1 & 0.70 & 0.80 \\
\hline 2006 & 0.8 & 0.9 & 0.70 & 1.5 & 1.10 & 1.60 \\
\hline 2007 & 1.1 & 1.1 & 1.20 & 0.8 & 0.80 & 0.60 \\
\hline 2008 & 1.0 & 1.2 & 1.20 & 1.1 & 1.40 & 1.50 \\
\hline 2009 & 1.0 & 1.1 & 1.10 & 1.0 & 1.30 & 1.30 \\
\hline 2010 & 1.1 & 0.8 & 0.80 & 1.1 & 0.90 & 0.90 \\
\hline 2011 & 0.9 & 0.9 & 0.80 & 0.9 & 0.70 & 0.60 \\
\hline 2012 & 1.0 & 1.2 & 1.20 & 0.9 & 0.90 & 0.80 \\
\hline 2013 & 0.9 & 0.8 & 0.70 & 0.9 & 0.80 & 0.70 \\
\hline 2015 & 1.1 & 1.8 & 1.90 & 1.1 & 1.10 & 1.20 \\
\hline 2016 & 1.1 & 1.1 & 1.20 & 1.2 & 2.20 & 2.60 \\
\hline 2017 & 0.9 & 1.1 & 0.90 & 0.9 & 1.10 & 0.90 \\
\hline 2018 & 0.8 & 0.3 & 0.20 & 0.7 & 0.20 & 0.10 \\
\hline 2019 & 1.3 & 1.4 & 1.80 & 1.0 & 0.40 & 0.40 \\
\hline $\mathrm{Sx}$ & 0.11 & 0.47 & 0.10 & 0.10 & 0.43 & 0.20 \\
\hline$\Delta \mathrm{x}$ & 0.23 & 0.98 & 0.21 & 0.21 & 0.90 & 0.42 \\
\hline
\end{tabular}


Table 3: Diagnostic predictors of the state of the phases of the population dynamics of non-gregarious locust pests in Northern Kazakhstan The phase of pest population dynamics

\begin{tabular}{|c|c|c|c|c|c|}
\hline \multirow[b]{2}{*}{ Diagnostic indicators } & \\
\hline & Depression & $\begin{array}{l}\text { Population } \\
\text { increase }\end{array}$ & $\begin{array}{l}\text { Mass } \\
\text { reproduction }\end{array}$ & $\begin{array}{l}\text { Population } \\
\text { peak }\end{array}$ & $\begin{array}{l}\text { Population } \\
\text { decrease }\end{array}$ \\
\hline Relative colonization, \%/Asur & $0-35$ & $35-75$ & $75-100$ & $75-50$ & $50-35$ \\
\hline Absolute colonization, individuals/Asur & $0-2$ & $2-4$ & $4-6$ & $6-4$ & $4-2$ \\
\hline Energy of dispersal & $0.1-0.9$ & $0.9-1.1$ & $1.1-2.0$ & $2.0-0.9$ & $0.9-0.1$ \\
\hline Energy of reproduction & $0.1-0.7$ & $0.7-1.5$ & $1.5-1.7$ & $1.7-0.7$ & $0.7-0.1$ \\
\hline Coefficient of reproduction & $0.1-0.7$ & $0.7-1.2$ & $1.2-1.6$ & $1.6-0.7$ & $0.7-0.1$ \\
\hline Coefficient of progradation & $0.1-0.3$ & $0.3-1.5$ & $1.5-3.3$ & $3.3-0.3$ & $0.3-0.1$ \\
\hline
\end{tabular}

Table 4: The established phases of the population dynamics of non-gregarious locusts depending on diagnostic predictors, 1999-2019

The phase of pest population dynamics

\section{Depression \\ Population increase}

Mass reproduction

Population peak

Population decrease
Analyzed years

2002,2003

2001, 2004, 2007, 2008, 2015, 2019

$1999,2005,2009,2012,2016$

2010, 2013, 2017

2000, 2006, 2011, 2014, 2018

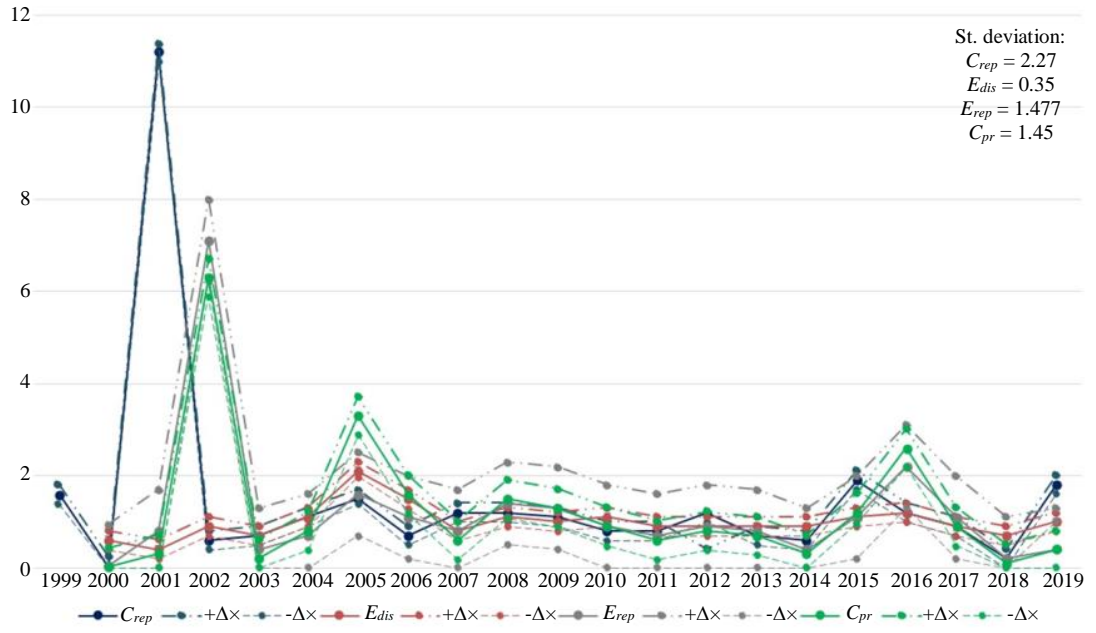

Fig. 1: Dynamics of the abundance indices of non-gregarious locust coefficients of reproduction $\left(C_{r e p}\right)$ and progradation $\left(C_{p r}\right)$ and the energy of dispersal $\left(E_{d i s}\right)$ and reproduction $\left(E_{r e p}\right)$ by years in Northern Kazakhstan, 1999-2019
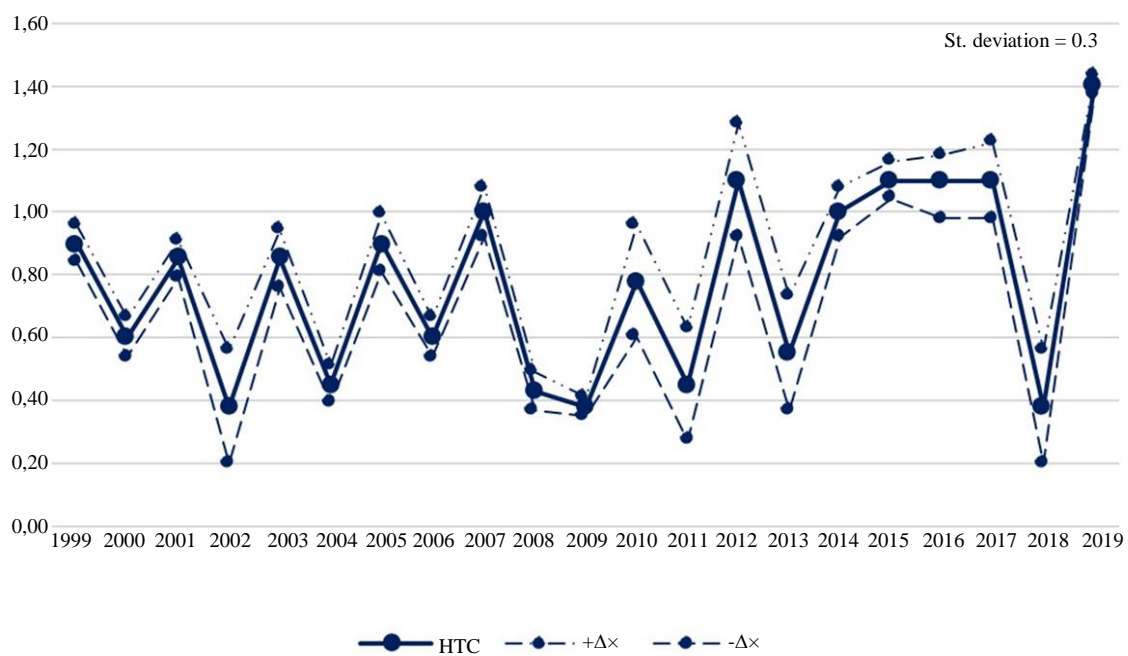

Fig. 2: Dynamics of the HTC indicator by years, on average in Northern Kazakhstan for 1999-2019 

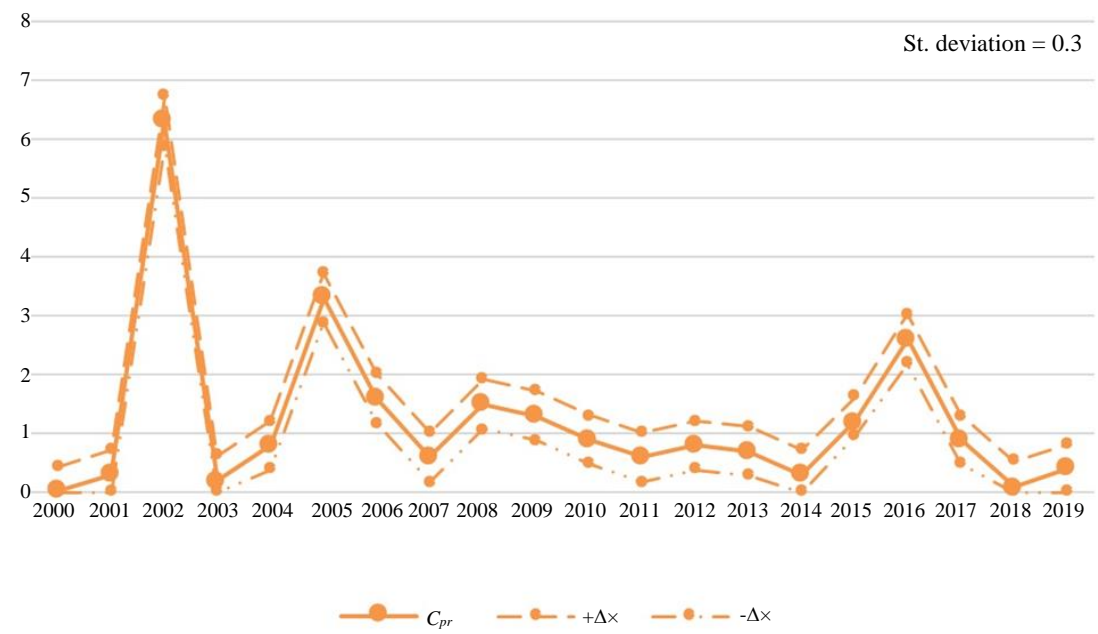

Fig. 3: Dynamics of the indicator of the coefficient of progradation $\left(C_{p r}\right)$ by years, on average in Northern Kazakhstan for $1999-2019$

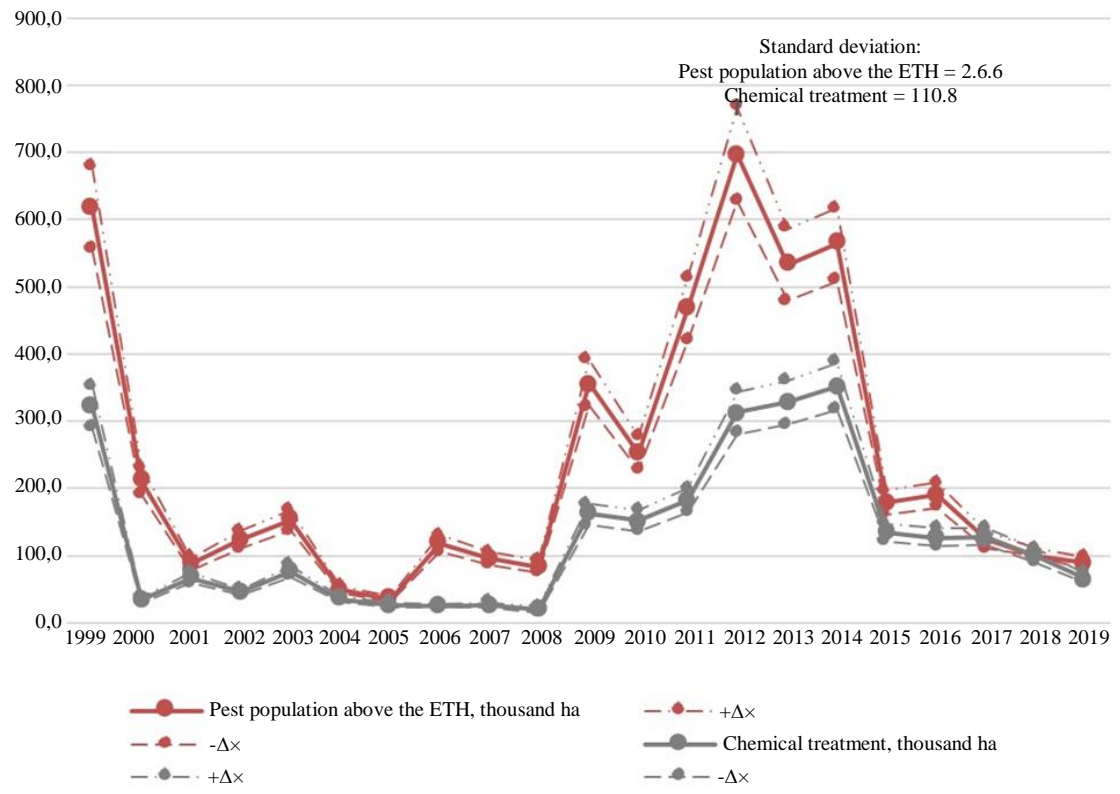

Fig. 4: Population dynamics by years in the area infested by non-gregarious locust pests above the ETH and volume of chemical treatments with pesticides in Northern Kazakhstan in 1999-2019

From the data in Figures 2 and 3, it can be seen that the infested areas with the pest population above the ETH were treated on average by 53.4 and $46.6 \%$ of the infested locust lands remained uncultivated. The situation is even worse in the years where high numbers of non-gregarious locusts are observed, i.e., in 1999, 2009, 2010, 2011, 2012, 2013 and 2014. During this period, only 1 million 810 thousand hectares were treated with pesticides, which is $51.9 \%$ of the area subject to treatment with a pest population above the ETH ( 3 million 488 thousand hectares) and 1 million 678 thousand hectares (or $48.1 \%$ ) of the area infected by locusts remained untreated.
Serious omissions in the organization of chemical treatments lead to a sharp deterioration in the phytosanitary situation due to the migration of locusts from untreated dangerous foci and their colonization of new territories. Such violations of the chemical treatment regulations undoubtedly lead to an increase in the distribution of locusts for the next year (Azhbenov et al., 2017).

An analysis of the long-term experience of locust control companies showed that the technology of massive pesticide treatments had the following undesirable consequences (Kurishbaev and Azhbenov, 2013; Baibussenov et al., 2014; Azhbenov et al., 2015): 
- In the context of global climate change, the effectiveness of the technology was low and did not provide suppression of dangerous pests

- Due to the extermination of natural enemies and natural epizootics, the duration of the locust mass reproduction phase was extended

- The violation of the processing regulations and the presence of flaws became a factor of migration, colonization of new territories and damage from locusts

- Pesticide treatments had undesirable effects on the environment and increased the pesticide load on ecosystems

We believe that the only possible alternative to the technology of massive pesticide treatments is the preventive control of locusts, which has a solid scientific basis and is confirmed by extensive practice (Kurishbaev and Azhbenov, 2013; Baibussenov et al., 2014; Azhbenov et al., 2015).

\section{Conclusion}

One of the most pressing issues of the modern development of agriculture is the problem of land infestation by gregarious and non-gregarious locusts in the context of global warming. So far, the only method used against locusts is the massive use of pesticides, based on the high biological effect of chemicals on the insect, although it is known that this technology often leads to undesirable consequences. The locust control strategy should change depending on scientific and technological progress, agricultural technologies and attitude to environmental protection. In this regard, studies of the population dynamics of non-gregarious locust pests to improve phytosanitary control are highly relevant.

Based on the results of the research carried out, it is possible to draw the following conclusions:

1. Periodic mass dispersions of non-gregarious locusts in agricultural regions of Northern Kazakhstan are becoming a risk factor for the production of economically important cultivated plants due to the polyphagous nature of those phytophages and the immediate proximity of agricultural lands to dangerous foci

2. For the first time, the developed diagnostic predictors of the population dynamics phase are used to analyze the population dynamics of nongregarious locusts. The greatest prognostic value is represented by year-to-year variations in the relative and absolute population $\left(\mathrm{Col}_{\text {rel }}, \mathrm{Col}_{a b s}\right)$, the population indices such as the energy of dispersal and reproduction $\left(E_{d i s}, E_{r e p}\right)$ and the coefficients of reproduction and progradation $\left(C_{r e p}, C_{p r}\right)$
3. We have established a relationship between the population dynamics of non-gregarious locusts and HTC. It was revealed that the population increase coincided with dry and hot or warm years (HTC $>0.20$ 0.55 ) and the population decline was observed mainly in cool and rainy years with $\mathrm{HTC} \leq 0.70-0.90$

4. Violations of the regulations for chemical treatments have a significant impact on the population dynamics of non-gregarious locusts. Thus, the analysis of the population dynamics by years of locust colonization and the volume of chemical treatments in Northern Kazakhstan for 1999-2019 showed that 46.6-48.1\% of the areas to be treated with a pest population higher than the ETH remained unprocessed. Violations of the regulations on chemical treatments lead to an increase in the spread and harmfulness of locusts.

5. The traditional technology of massive pesticide treatments requires enormous costs, destabilizes the ecological situation and increases the pesticide load on ecosystems. Great opportunities appear as a result of the transition to preventive technology for locust control based on the use of gentle plant protection products to reduce the negative impact of pesticides on the environment, the use of modern methods of phytosanitary monitoring

\section{Acknowledgement}

This study was carried out with the support of the Science Committee of the Ministry of Education and Science of the Republic of Kazakhstan, within the framework of the scientific grant IRN AP08052747 "Phytosanitary control of non-gregarious locusts in agricultural areas of Northern Kazakhstan based on the innovation of GIS technologies and methods of remote sensing of the Earth".

\section{Author's Contributions}

All authors equally contributed in this work.

\section{Ethics}

This article is original and contains unpublished material. The corresponding author confirms that all of the other authors have read and approved the manuscript and no ethical issues involved.

\section{References}

Abdalla, A. M. (2014). Towards ameliorated locusts and grasshopper management in Western Sudan. Third conference of pests management in Sudan, February 3-4, 2014, Wad Medani, Sudan, 5; 19-23. http://rmebrk.kz/journals/4561/48004.pdf 
Akmollaeva, A. S. (2004). Vidovoi sostav nestadnykh saranchovykh na razlichnykh biotopakh [The species composition of non-gregarious locusts in different biotopes]. Mezhdunarodnaya nauchnaya konferentsiya "Strategiya nauchnogo obespecheniya APK RK v otraslyakh zemledeliya, rastenievodstva i sadovodstva: realnost i perspektivy" [International scientific conference "Strategy of scientific support of the agroindustrial complex of the Republic of Kazakhstan in the fields of agriculture, crop growing and gardening: reality and perspectives"], June 2-4, Agrouniversitet, Almaty, Kazakhstan, pp: 202-203. http://rmebrk.kz/journals/4561/48004.pdf

Ariel, G., \& Ayali, A. (2015). Locust collective motion and its modeling. PLoS Computational Biology, 11(12), e1004522. https://doi.org/10.1371/journal.pcbi.1004522

Axelsen, J. R. A., Petersen, B. S., Maiga, I. H., Niassy, A., Badji, K., Ouambama, Z., ... \& Kooyman, C. (2009). Simulation studies of Senegalese Grasshopper ecosystem interactions II: the role of egg pod predators and birds. International Journal of Pest Management, 55(2), 99-112. https://doi.org/10.1080/09670870802617171

Azhbenov, V. K. (2013). Rukovodstvo dlya vypolneniya monitoringovykh rabot po italyanskoi saranche $\mathrm{s}$ ispolzovaniem GPS-tekhnologii [A manual for monitoring the Italian locusts with the use of GPS technologies]. Astana, pp: 41. http://rmebrk.kz/journals/4561/48004.pdf

Azhbenov, V. K., Kostyuchenkov, N. V., Sarbaev, A. T., Baibusenov, K. S., Suleimenova, Z. Sh., \& Zagainov, N. A. (2017). Italyanskaya sarancha (Calliptamus italicus L.) $\mathrm{v}$ Kazakhstane [The Italian locust in Kazakhstan]. Astana. ISBN: 978-9965-799-54-9, pp: 121. http://rmebrk.kz/journals/4561/48004.pdf

Azhbenov, V. K., Kurishbaev, A. K., Sarbaev, A. T., Kharizanova, V. B., \& Baibusenov, K. S. (2015). Fitosanitarnaya bezopasnost ot nashestviya saranchi v svyazi s globalnymi izmeneniyami klimata [Phytosanitary safety against locust infestation due to global climate change]. "Globalnye izmeneniya klimata i bioraznoobrazie", II Mezhdunarodnyi Biologicheskii Kongress ["Global climate change and biodiversity", 2nd International Biological Congress], Nov. 11-13, Almaty, Kazakhstan, pp: 25-30. http://rmebrk.kz/journals/4561/48004.pdf

Baibusenov, K. S., Azhbenov, V. K., \& Sarbaev, A. T. (2014). Areal i vredonosnost nestadnykh saranchovykh v Severnom Kazakhstane [The area and harmfulness of non-gregarious locusts in Northern Kazakhstan]. Materialy mezhdunarodnoi nauchno-prakticheskoi konferentsii "Integratsiya nauki i proizvodstva $\mathrm{v}$ agropromyshlennom komplekse" [Materials of the international research and practice conference "Integration of science and production in the agroindustrial complex"], PGU, Pavlodar, Kazakhstan, pp: 22-27. http://rmebrk.kz/journals/2934/41025.pdf
Baibussenov, K. S., Sarbaev, A. T., Azhbenov, V. K., \& Harizanova, V. B. (2014). Environmental features of population dynamics of hazard nongregarious locusts in northern Kazakhstan. Life Science Journal, New York, 11(10s), 277-281. https://lifesciencesite.com/lsj/life1110s/049_25529li fe1110s14_277_281.pdf

Baybussenov, K. S., Sarbaev, A. T., Azhbenov, V. K., \& Harizanova, V. B. (2015). Predicting the phase state of the abundance dynamics of harmful nongregarious Locusts in Northern Kazakhstan and substantiation of protective measures. Biosci. Biotechnol. Res. Asia, 12, 1535-1543. https://doi.org/10.13005/bbra/1814

Childebaev, M. K., \& Kazenas, V. L. (2013). Pryamokrylye (tip Chlenistonogie, klass Nasekomye). Seriya "Zhivotnye Kazakhstana v fotografiyakh" [Orthoptera (type: Arthropods, class: Insects). "The Animals of Kazakhstan in photographs" series]. Nur-Print, Almaty, pp: 127. http://antvid.org/Kazenas/PDF/Publ\%202/chiljdebae v2013_prjamokrylye_kz.pdf

Cressman, K. (2016). Desert locust. In: Biological and Environmental Hazards, Risks and Disasters, Sivanpillai, R., (Ed.), Elsevier, Amsterdam, Neth, pp: 87-105. http://www.fao.org/ag/locusts/common/ecg/190/en/1 512_Bio_hazard_book_chapter.pdf

Dubrovin, V. V., Tenyaeva, O. L., \& Kritskaya, V. P. (2011). Metody fitosanitarnogo monitoringa $\mathrm{V}$ zashchite rastenii ot vrednykh organizmov [Phytosanitary monitoring methods in plant protection from pests]. Saratov State Agrarian University N.I. Vavilova, Saratov. ISBN: 978-57011-0706-7, pp: 230. http://www.sgau.ru/kadry/dubrovin-vladimirviktorovich

FAOUN. (2014). Evaluation of field trials data on the efficacy and selectivity of insecticides on locusts and grasshoppers: report to FAO by the Pesticide Referee Group. Rep., Rome, Italy. Food and Agriculture Organization of the United Nations. http://www.fao.org/ag/locusts/common/ecg/2241/en/ PRG10e.pdf

FAOUN. (2020). Locust watch: locusts in Caucasus and Central Asia. Food and Agriculture Organization of the United Nations. http://www.fao.org/ag/locustsCCA/en/index.html

Hassanali, A., Njagi, P. G., \& Bashir, M. O. (2005). Chemical ecology of locusts and related acridids. Annual review of entomology, 50, 223. https://doi.org/10.1146/annurev.ento.50.071803.1 30345 
Kurishbaev, A. K., \& Azhbenov, V. K. (2013). Preventivnyi podkhod $\mathrm{V}$ reshenii problemy nashestviya saranchi $v$ Kazakhstane i sopredelnykh territoriyakh [A preventive approach in solving the problem of the locust infestation in Kazakhstan and the neighboring territories]. Vestnik nauki KazATU im. S. Seifullina, $\quad 1 ; \quad$ (76); 42-52. https://kazatu.edu.kz/assets/i/science/vn1301agr0 1.pdf

Latchininsky, A. V., \& Sivanpillai, R. (2010). Locust habitat monitoring and risk assessment using remote sensing and GIS technologies. In Integrated Management of Arthropod Pests and Insect Borne Diseases (pp. 163-188). Springer, Dordrecht. https://doi.org/10.1007/978-90-481-8606-8_7

Lockwood, J. A., \& Sergeev, M. G. (2000). Comparative biogeography of grasshoppers (Orthoptera: Acrididae) in North America and Siberia: Applications to the conservation of biodiversity. Journal of Insect Conservation, 4(3), 161-172. https://doi.org/10.1023/A:1009618425473

Lomer, C. J., Bateman, R. P., Johnson, D. L., Langewald, J., \& Thomas, M. (2001). Biological control of locusts and grasshoppers. Annual Review of Entomology, 46(1), 667-702. https://doi.org/10.1146/annurev.ento.46.1.667

Malakhov, D. V., \& Zlatanov, B. V. (2020). An Ecological Niche Model for Dociostaurus maroccanus, Thunberg, 1815 (Orthoptera, Acrididae): The Nesting Environment and Survival of Egg-Pods. Biosis: Biological Systems, 1(01), 08-24. https://doi.org/10.37819/biosis.v1i1.48

MARK. (1999-2019). Obzor rasprostraneniya vrednykh organizmov selskokhozyaistvennykh kultur V Kazakhstane v 1999-2019 gg. i prognoz ikh poyavleniya [A review of the distribution of crop pests in Kazakhstan in 1999-2019 and a forecast of their appearance]. MSKh RK, Alma-Ata /Astana. Ministry of Agriculture of the Republic of Kazakhstan.

McNary, T. J., Shambaugh, B. A., Elliston, R. J., \& Brown, C. L. (2011). Cooperative rangeland grasshopper suppression in Wyoming (USA) in 2010. Metaleptea, 31(1), 10-12.

Sagitov, A. O., \& Duisembekov, B. A. (2016). Fitosanitarnyi monitoring vrednykh i osobo opasnykh vrednykh organizmov (vreditelei, boleznei, sornykh rastenii): (uchebnoe posobie) [Phytosanitary monitoring of hazardous and especially dangerous hazardous organisms (pests, diseases, weeds): a manual]. 3rd edition in Kazakh. Kazakhskii NIIZiKR, Almaty, pp: 376. http://kazatu.edu.kz/assets/i/science/sf16-agro107.pdf
Sergeev, M. G. (2010). Vrednye saranchovye Rossii i sopredelnykh regionov: proshloe, nastoyashchee, budushchee [Locust pests in Russia and the adjacent regions: the past, the present, the future]. Zashchita $i$ Karantin Rastenii, 1; 18-22. http://www.z-i-kr.ru/interest/interestsergeev.html

SICAICMARK, (2020). Spisok pestitsidov, razreshennykh $\mathrm{k}$ proizvodstvu (formulyatsii), vvozu, khraneniyu, transportirovke, realizatsii i primeneniyu na territorii Respubliki Kazakhstan na 2013-2022 gody [List of pesticides allowed for production (formulation), import, storage, transportation, sale and use on the territory of the Republic of Kazakhstan for 2013-2022]. https://www.gov.kz/memleket/entities/agroindust/ activities $/ 2789$ ?lang=ru

Stolyarov, M. V. (2000). Cyclicity and some characteristics of mass reproduction of Calliptamus italicus L. in southern Russia. Russian Journal of Ecology, 31(1), 43-48. https://doi.org/10.1007/BF02799725

Tokbergenova, A., Kiyassova, L., \& Kairova, S. (2018). Sustainable Development Agriculture in the Republic of Kazakhstan. Polish Journal of Environmental Studies, 27(5). https://doi.org/10.15244/pjoes/78617

Toleubayev, K., Jansen, K., \& van Huis, A. (2007). Locust control in transition: the loss and reinvention of collective action in post-Soviet Kazakhstan. Ecology and Society, 12(2). https://doi.org/10.5751/es-02229-120238

Yao, Sh.-R., \& Zhang, W.-Z. (2007). Effects of El Nio, La Nina and solar activities on the outbreaks of the summer locust in Hebei Province. Chinese Journal of Eco-Agriculture, 02, http://en.cnki.com.cn/Article_en/CJFDTotalZGTN200702037.htm

Yu, G., Shen, H., \& Liu, J. (2009). Impacts of climate change on historical locust outbreaks in China. Journal of Geophysical Research: Atmospheres, 114(D18). https://doi.org/10.1029/2009jd011833

Zhang, L., Lecoq, M., Latchininsky, A., \& Hunter, D. (2019). Locust and grasshopper management. Annual Review of Entomology, 64, 15-34. https://doi.org/10.1146/annurev-ento-011118112500 